\title{
Identification of bacteria in enrichment cultures of sulfate reducers in the Cariaco Basin water column employing Denaturing Gradient Gel Electrophoresis of $16 \mathrm{~S}$ ribosomal RNA gene fragments
}

Lorelei Bozo-Hurtado', M Alexandra García-Amado², Andrei Chistoserdov³, Ramon Varela ${ }^{4}$ J Jesus Narvaez ${ }^{4}$ Rita Colwell ${ }^{5}$ and Paula Suárez ${ }^{1 *}$

\begin{abstract}
Background: The Cariaco Basin is characterized by pronounced and predictable vertical layering of microbial communities dominated by reduced sulfur species at and below the redox transition zone. Marine water samples were collected in May, 2005 and 2006, at the sampling stations $\mathrm{A}\left(10^{\circ} 30^{\prime} \mathrm{N}, 64^{\circ} 40^{\prime} \mathrm{W}\right), \mathrm{B}\left(10^{\circ} 40^{\prime} \mathrm{N}, 64^{\circ} 45^{\prime} \mathrm{W}\right)$ and D $\left(10^{\circ} 43^{\prime} \mathrm{N}, 64^{\circ} 32^{\prime} \mathrm{W}\right)$ from different depths, including surface, redox interface, and anoxic zones. In order to enrich for sulfate reducing bacteria (SRB), water samples were inoculated into anaerobic media amended with lactate or acetate as carbon source. To analyze the composition of enrichment cultures, we performed DNA extraction, PCR-DGGE, and sequencing of selected bands.

Results: DGGE results indicate that many bacterial genera were present that are associated with the sulfur cycle, including Desulfovibrio spp., as well as heterotrophs belonging to Vibrio, Enterobacter, Shewanella, Fusobacterium, Marinifilum, Mariniliabilia, and Spirochaeta. These bacterial populations are related to sulfur coupling and carbon cycles in an environment of variable redox conditions and oxygen availability.

Conclusions: In our studies, we found an association of SRB-like Desulfovibrio with Vibrio species and other genera that have a previously defined relevant role in sulfur transformation and coupling of carbon and sulfur cycles in an environment where there are variable redox conditions and oxygen availability. This study provides new information about microbial species that were culturable on media for SRB at anaerobic conditions at several locations and water depths in the Cariaco Basin.
\end{abstract}

Keywords: SRB, Cariaco Basin, Desulfovibrio, Vibrio, DGGE, Culture

\section{Background}

The Cariaco system is a depression located on the northern continental shelf of Venezuela in the Caribbean Sea and is largest true marine permanently anoxic marine water body in the world. The Basin, $160 \mathrm{~km}$ long and $50 \mathrm{~km}$ wide, is divided into two sub-basins, each with a maximum depth of $1400 \mathrm{~m}$ and separated by a saddle at $900 \mathrm{~m}$ water depth.

\footnotetext{
*Correspondence: pulisuarez@gmail.com

'Departamento de Biología de Organismos, Universidad Simón Bolívar,

Caracas, Venezuela

Full list of author information is available at the end of the article
}

Based on redox conditions and oxygen content, the basin is divided into three layers: oxic $(\sim 0-250 \mathrm{~m})$; redox transition $(\sim 250-450 \mathrm{~m})$; and anoxic $(\sim 450$ to $1400 \mathrm{~m})$ [1-4]. The basin water column is characterized by a pronounced vertical layering of microbial communities. The oxic layer possesses the most complex trophic structure, dominated by processes such as photosynthesis, aerobic heterotrophy and nitrification. The redox transition zone is biogeochemically stratified, appears less complex and predominant processes are chemoautotrophy, fermentation, denitrification, and anaerobic respiration.
Ciomed Central

(c) 2013 Bozo-Hurtado et al.; licensee BioMed Central Ltd. This is an Open Access article distributed under the terms of the Creative Commons Attribution License (http://creativecommons.org/licenses/by/2.0), which permits unrestricted use,

distribution, and reproduction in any medium, provided the original work is properly cited. 
The anoxic zone presumably has the simplest trophic structure that appears to be supported by fermentation, sulfate reduction, methanogenesis and anaerobic methane oxidation [3]. Many studies have been conducted in the Cariaco Basin to understand how microorganisms are distributed in the stratified water column environment and how they influence geochemical processes $[1,3,5]$. Interestingly, high levels of sulfide present in the Cariaco Basin have been attributed to biological sulfate reduction [6]. This is the first attempt to identify bacteria related with sulfate reduction using enrichments cultures for the Cariaco Basin.

Several studies have been published describing the microbial community associated with the Cariaco Basin sulfur cycle. Tuttle and Jannasch (1973) isolated several sulfide and thiosulfate-oxidizing bacteria and Morris et al. (1985) isolated Alteromonas sp. from thiosulfate-containing enrichment cultures $[7,8]$. With the development of molecular biology, culture-independent methods have been used to detect SRB populations in the Cariaco Basin $[1,5,9]$. To explore the diversity of bacteria in the Cariaco Basin involved in sulfate reduction, we used SRB enrichment culture complemented with identification of the enriched bacteria by gradient gel electrophoresis (DGGE).

\section{Results}

Depth profiles of temperature, salinity, and dissolved oxygen in the water column at all stations for two years are shown in Table 1. Temperatures varied from 17.10 to $23.85^{\circ} \mathrm{C}$, with the greater variation between the surface and interface zone. Salinity was stable throughout the water column at all depths and stations sampled, ranging between 36.26 to 36.88 PSU. Dissolved $\mathrm{O}_{2}$ concentration peaked at $40 \mathrm{~m}(4.009 \mathrm{~mL} / \mathrm{L})$ and declined dramatically at depths below $200 \mathrm{~m}$. The maximum measured sulfide concentration was obtained at the greatest depth for all stations during both years of sampling. These physicochemical patterns are typical of the Cariaco Basin, showing redox zonation and similar to those reported by other authors [2,4,6-12].

Table 1 Physico-chemical parameters measured in the Cariaco Basin during the study

\begin{tabular}{|c|c|c|c|c|c|c|}
\hline \multicolumn{7}{|c|}{ Year 2005} \\
\hline Station & Zone & Depth (m) & Temperature $\left({ }^{\circ} \mathrm{C}\right)$ & Salinity (PSU) & Dissolved $\mathrm{O}_{2}(\mathrm{~mL} / \mathrm{L})$ & ${ }^{*} \mathrm{H}_{2} \mathrm{~S}(\mu \mathrm{M})$ \\
\hline \multirow[t]{3}{*}{ A } & Oxic & 230 & 17.90 & 36.43 & $0.0738^{\dagger}$ & $\mathrm{ND}$ \\
\hline & Interface & 270 & 17.69 & 36.39 & 0.0688 & 1.22 \\
\hline & Anoxic & 900 & 17.03 & 36.26 & 0.0653 & 51.47 \\
\hline \multirow[t]{3}{*}{ B } & Oxic & 235 & 17.83 & 36.42 & $0.0711^{\dagger}$ & ND \\
\hline & Interface & 275 & 17.63 & 36.38 & 0.0674 & 0.69 \\
\hline & Anoxic & 670 & 17.06 & 36.27 & 0.0646 & ND \\
\hline \multicolumn{7}{|c|}{ Year 2006} \\
\hline Station & Zone & Depth (m) & Temperature $\left({ }^{\circ} \mathrm{C}\right)$ & Salinity (PSU) & Dissolved $\mathrm{O}_{2}(\mathrm{~mL} / \mathrm{L})$ & ${ }^{*} \mathrm{H}_{2} \mathrm{~S}(\mu \mathrm{M})$ \\
\hline \multirow[t]{4}{*}{ A } & Oxic & 100 & 21.08 & 36.79 & 3.2116 & ND \\
\hline & Interface & 300 & 17.64 & 36.36 & 0.0157 & 5.39 \\
\hline & Anoxic & 400 & 17.46 & 36.33 & 0.0113 & 14.3 \\
\hline & & 500 & 17.23 & 36.29 & 0.0113 & 25.55 \\
\hline \multirow[t]{5}{*}{ B } & Oxic & 215 & 17.97 & 36.41 & $0.0245^{\dagger}$ & ND \\
\hline & Interface & 260 & 17.75 & 36.38 & 0.0122 & 6.62 \\
\hline & & 290 & 17.70 & 36.37 & 0.0129 & 7.07 \\
\hline & Anoxic & 325 & 17.57 & 36.35 & 0.0131 & 11.09 \\
\hline & & 640 & 17.10 & 36.26 & 0.0186 & 38.46 \\
\hline \multirow[t]{5}{*}{ D } & Oxic & 40 & 23.85 & 36.88 & 4.0087 & ND \\
\hline & & 180 & 18.18 & 36.45 & 0.5738 & ND \\
\hline & Interface & 270 & 17.80 & 36.39 & 0.0135 & 0.21 \\
\hline & Anoxic & 365 & 17.52 & 36.34 & 0.0197 & 13.31 \\
\hline & & 500 & 17.40 & 36.33 & 0.0196 & 18.86 \\
\hline
\end{tabular}

*Data from http://www.imars.usf.edu/CAR/.

${ }^{+}$Low DO values in oxic zones over the limit of interface layer where DO decays and $\mathrm{H}_{2} \mathrm{~S}$ increases. PSU: Practical Salinity Units.

$N D$ : Not determined. 


\section{Bacteria enrichments in SRB media}

Twenty-four cultures, in which black coloration with ferrous sulfide precipitation was observed, were selected for further investigation. Using TWIN pack medium, two cultures were obtained during 2005: one from station A and another from station B. Using TP medium, we obtained thirteen cultures during 2006: one from station A, six from station $\mathrm{B}$, and six from station $\mathrm{D}$. Using API medium, nine cultures were obtained during 2006: three from station A, two from station B and four from station D (Figure 1). All of the cultures had variable cell morphology, with curved rod-shaped bacteria with polar spores predominant.

\section{Molecular identification}

All 16S RNA gene amplicons from the 24 cultures were separated in the DGGE gels (Figure 1). The patterns comprised several bands, suggesting that different bacterial types were present. Sixty-seven DGGE bands were excised

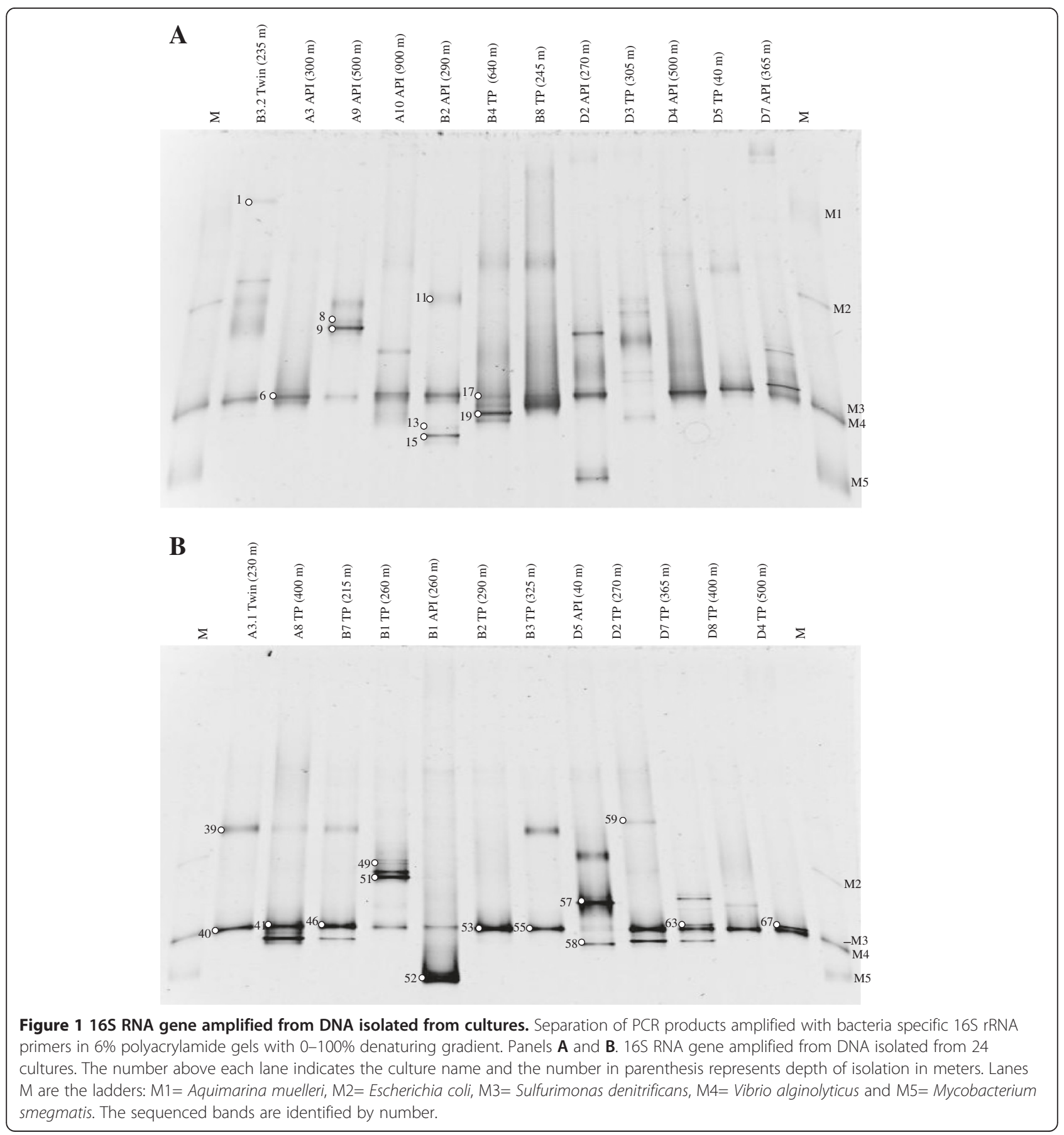


and sequenced, but only 23 quality sequences were generated. These sequences were compared with existing sequences in the NCBI public database using the BLAST algorithm. Results of the BLAST analyses are summarized in Table 2. A prevalent band in the DGGE gels was observed for all samples, except D3 TP (305 m). Bands showing similar mobility gave highly similar or identical sequences with the molecular marker M4 (Vibrio alginolyticus) (Figure 1). Several of these bands (6, 40, 41, $46,53,55$ and 63) were sequenced and shared 99-100\% similarity with Vibrio species, forming a linkage with $V$. campbelli, V. harveyi, and V. alginolyticus. Band 63 was distant from the main Vibrio species cluster, appearing to be more closely related to Vibrio fortis (98\%) (Figure 2). Additionally, two bands $(17,19)$ showed $96 \%$ similarity with the Vibrio cluster, forming a clade with $V$. shilonii and $V$. aestuarianus (Table 2 and Figure 2). These results indicate that Vibrio species are common in our enrichments from Cariaco Basin water column.

Three bands showing similar migration patterns had high sequence similarity (96-99\%) with the 16S rRNA of bacteria belonging to the Desulfovibrio genus (Figure 3). Bands 13 and 15 clustered with a Desulfovibrio sp. isolated from a shallow submarine hydrothermal system in a tropical environment [13]. Band 58 had 99\% similarity with an uncultured Desulfovibrio from sediment samples of a saline meromictic Lake in Japan [14] and clustered with D. zosterae at $\geq 96 \%$ similarity (Table 2 and Figure 3 ). The four other bands in the TP cultures from several depths (215-400 m), with similar patterns as Desulfovibrio, were observed (Figure 1) but not successfully sequenced. Over

Table 2 Bacteria detected in the present study

\begin{tabular}{|c|c|c|c|c|c|c|}
\hline Station & Zone & Depth & Culture/ Sample & Band & closest Blast relative (GenBank accession number) & $\%$ identity \\
\hline \multirow[t]{9}{*}{ A } & Oxic & $230 \mathrm{~m}$ & A3.1 TWIN & 39 & Uncultured bacterium clone 1NT1c10_D09 (GQ413739) & 99 \\
\hline & & & & & Uncultured Bacteroidetes bacterium clone PG-16-1-2 (EU626578) & 93 \\
\hline & & & & 40 & Vibrio parahaemolyticus (EU155540) & 99 \\
\hline & Interface & $300 \mathrm{~m}$ & A3 API & 6 & Vibrio sp. (EU854873) & 99 \\
\hline & Anoxic & $400 \mathrm{~m}$ & A8 TP & 41 & Vibrio parahaemolyticus (GU064371) & 99 \\
\hline & & $500 \mathrm{~m}$ & A9 API & 8 & Uncultured bacterium clone 1NT1c10_A05 (GQ413699). & 99 \\
\hline & & & & & Fusobacterium perfoetens (M58684) & 95 \\
\hline & & & & 9 & Uncultured bacterium clone 1NT1c10_A05 (GQ413699) & 99 \\
\hline & & & & & Fusobacterium perfoetens (M58684) & 97 \\
\hline \multirow[t]{16}{*}{ B } & Oxic & $215 \mathrm{~m}$ & B7 TP & 46 & Vibrio sp. (EU854855) & 99 \\
\hline & & $235 \mathrm{~m}$ & B3 2 TWIN & 1 & Uncultured bacterium clone SGUS1101 (FJ202956) & 99 \\
\hline & & & & & Uncultured Clostridia bacterium clone 4DP1-A6 (EU780347) & 99 \\
\hline & Interface & $260 \mathrm{~m}$ & B1 TP & 49 & Uncultured bacterium clone 1NT1c10_A05 (GQ413699) & 99 \\
\hline & & & & & Fusobacterium perfoetens (M58684) & 96 \\
\hline & & & & 51 & Uncultured bacterium clone 1NT1c10_A05 (GQ413699) & 99 \\
\hline & & & & & Fusobacterium perfoetens (M58684) & 96 \\
\hline & & & B1 API & 52 & Enterobacter cloacae ATCC13047-T (AJ251469) & 100 \\
\hline & & $290 \mathrm{~m}$ & B2 API & 11 & Uncultured bacterium clone RefT1c10 (GQ413678) & 99 \\
\hline & & & & & Marinifilum fragile (FJ394546) & 96 \\
\hline & & & & 13 & Desulfovibrio sp. An30N (AB301719) & 99 \\
\hline & & & & 15 & Desulfovibrio sp. An30N (AB301719) & 96 \\
\hline & & & B2 TP & 53 & Vibrio harveyi (HM008704) & 99 \\
\hline & Anoxic & $325 \mathrm{~m}$ & B3 TP & 55 & Vibrio parahaemolyticus (FJ547093) & 100 \\
\hline & & $640 \mathrm{~m}$ & B4 TP & 17 & Vibrio sp. (GU223598) & 99 \\
\hline & & & & 19 & Vibrio sp. (EF587982) & 98 \\
\hline \multirow[t]{5}{*}{$\mathrm{D}$} & Oxic & $40 \mathrm{~m}$ & D5 API & 57 & Spirochaeta sp. Antartic (M87055) & 95 \\
\hline & & & & 58 & Uncultured bacterium clone L-D-2 (AB154510) Desulfovibrio sp. & 98 \\
\hline & Interface & $270 \mathrm{~m}$ & D2 TP & 59 & Marinilabilia salmonicolor strain AQBPPR1 (GU198996) & 95 \\
\hline & Anoxic & $365 \mathrm{~m}$ & D7 TP & 63 & Vibrio sp (FJ952814) & 99 \\
\hline & & $500 \mathrm{~m}$ & D4 TP & 67 & Shewanella sp (GQ203107) & 98 \\
\hline
\end{tabular}




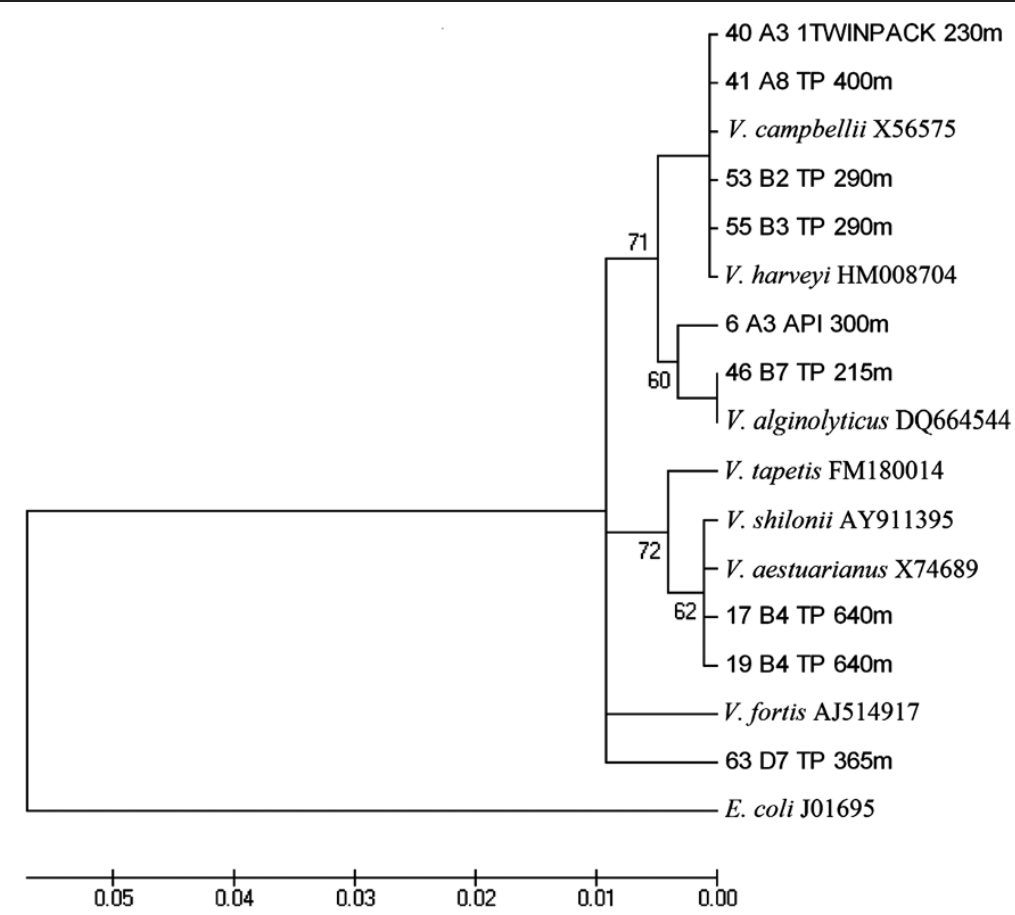

Figure 2 Phylogenetic tree of partial 16S rRNA sequences of genus Vibrio isolated from the Cariaco Basin. Tree was constructed using Neighbor-Joining algorithm. Bootstrap values are based on 1000 replicates and no values are given for groups with Bootstrap values less than $50 \%$. The scale bar represents 0.01 (1\%) nucleotide sequence difference.

all, the results indicate that several Desulfovibrio species are present in the Cariaco water column at depths between 40 to $400 \mathrm{~m}$ (Table 2).

A representative of another genus located at the interface at station $\mathrm{B}$ and in the anoxic zone at station A was Fusobacterium, represented by four bands (Table 2). Bands 9, 49, and 51 showed 100\% similarity and $99 \%$ with band 8 , forming a group with an uncultured bacterium clone (GQ413699) and Fusobacterium perfoetens (Figure 3). Sequences belonging to Enterobacter, Shewanella, Marinifilum, Mariniliabilia and Spirochaeta were also identified in the Cariaco Basin water column enrichments (Table 2 and Figure 3). Enterobacter cloacae, a $\gamma$-proteobacteria was detected at $260 \mathrm{~m}$ in the interface zone of Station B. Spirochaeta sp., Mariniliabilia sp. and Shewanella sp. were found in the oxic $(40 \mathrm{~m})$, interface $(270 \mathrm{~m})$, and anoxic $(500 \mathrm{~m})$ zones, respectively, at Station D. Bands 63 (Vibrio sp.) and 67 (Shewanella sp.) had a similar migration pattern (Figure 1) and their sequences were $94 \%$ similar. Both, however, belong to $\gamma$-proteobacteria (Figure 3). Band 59 had 96\% similarity with Mariniliabilia, an uncultured clone from a saltern evaporative lagoon in Puerto Rico, belonging to the Bacteroidales, while band 57 had 95\% similarity with a Spirochaeta strain isolated in Antarctica (Figure 3).

Band 11 from the interface at station B $(290 \mathrm{~m})$ showed 96\% similarity with Marinifilum fragile and 99\% with an uncultured bacterium clone from coral reef samples in the Philippines [15]. The last of the bands that were sequenced (1 and 39) were from the oxic zone of Station A and matched with uncultivated clones most closely related to the Firmicutes and Bacteroidetes phyla (Table 2 and Figure 3). All eight genera detected in this study are strictly or facultative anaerobic bacteria with some relationship to sulfur cycling.

\section{Discussion}

Isolation of the vast majority of bacteria in pure culture from the environment is hindered by lack of knowledge of specific culture conditions and by the potential synergism between organisms [16]. Recently, molecular approaches, such as rRNA analysis, have been used to determine bacterial species composition of microbial communities [16,17] and sequences of genes allow grouping and identification of the microorganisms. Genetic fingerprinting of microbial communities by DGGE provides banding patterns that reflect the genetic diversity of the community [16] or, as in this study, the diversity of a portion of the culturable community. DGGE of PCR-amplified gene fragments is one of the fingerprinting techniques used to separate fragments of identical length on the basis of primary sequence and base composition [16,17]. Different DGGE bands, indicating several different bacteria were detected and sequenced and the bands were identified as being derived 


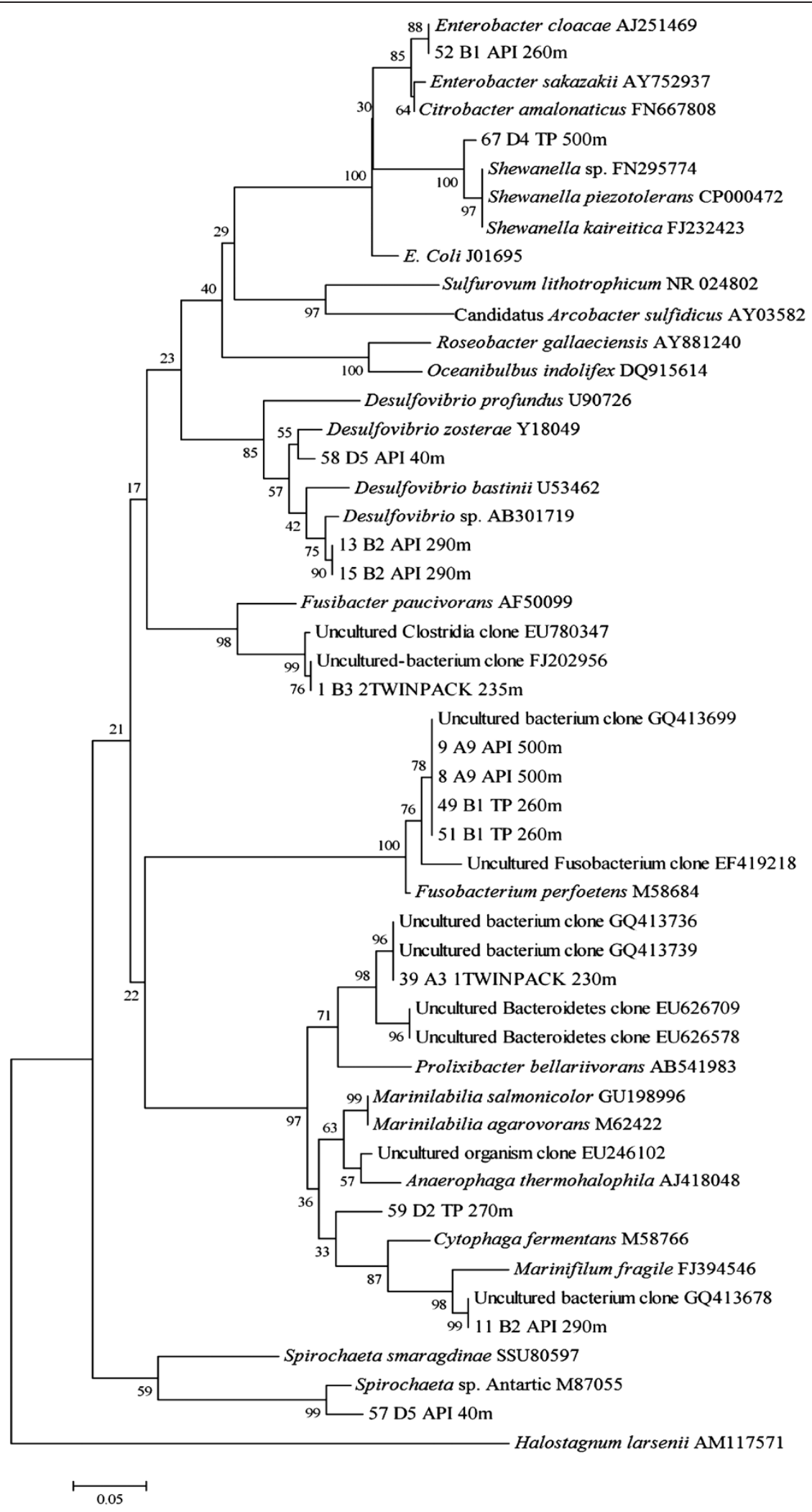

Figure 3 Phylogenetic tree of partial 16S rRNA sequences obtained from the Cariaco Basin. Tree was constructed using Neighbor-Joining algorithm. Bootstrap values are based on 1000 replicates. The scale bar represents 0.05 (5\%) nucleotide sequence difference. 
from the genera Vibrio, Desulfovibrio, Enterobacter, Shewanella, Fusobacterium, Marinifilum, Mariniliabilia and Spirochaeta. Although 200bp sequence length can be considered too short for a phylogenetic analyses we founded that ours sequences correspond to genera, groups and classes like Vibrio sp., CFB group, gamma and delta proteobacteria that has been reported in the water column of the Cariaco basin previously $[1,5,9,10,12]$.

The genus Vibrio encompasses a diverse group of heterotrophic marine bacteria and is widespread in the aquatic environment, occupying a variety of ecological niches. There are indications that vibrios play a role in nutrient cycling by taking up dissolved organic matter [18]. Vibrio-affiliated sequences were detected by DGGE gel analysis in the sample from both years (Figure 1) and 16S rRNA sequence similarity with of $V$. campbellii, $V$. harveyi, and $V$. alginolyticus (Figure 2). The Vibrio core cluster (including Vibrio harveyi, $V$. alginolyticus and $V$. campbellii) is often difficult to resolve solely by $16 \mathrm{~S}$ rRNA gene heterogeneity, since species within the $V$. harveyi clade has a very high degree of both genetic and phenotypic similarity. These species have more than $99 \%$ sequence identity in the $16 \mathrm{~S}$ rRNA gene $[19,20]$.

Vibrio harveyi is found in a free-living state in aquatic environments and as part of the normal microbiota of marine animals. However, many variants of $V$. harveyi have been recognized as significant pathogens of aquacultured marine fish [21,22], crustaceans [23], lobsters [24], and corals [25]. Moreover, since 1993, $V$. harveyi has been recovered from diseased fish and penaeids in Venezuelan waters close to the Cariaco Basin (Paria Peninsula, Sucre State) [21].

Three bands 17, 19 and 63 had low 16S rRNA similarity (around 96-98\%) with known vibrio species (Figure 2). Bands 17 and 19 were $96 \%$ similar to Vibrio shilonii. This species has been associated with healthy or necrotic corals in the Caribbean and Pacific reefs [18,26-30]. V. shilonii has recently reported in Cariaco Basin waters in the oxic layer using specific primers for Vibrio species in Station A [12] while we founded at $640 \mathrm{~m}$ depth (anoxic zone) in Station B. Band 63 is more closely related to $V$. fortis (98\%). This species was detected directly in water samples between $200 \mathrm{~m}$ and $1300 \mathrm{~m}$ of the Station A in a previous report [12] were becomes a prominent Vibrio sp. in the redoxcline and anoxic zone. Furthermore, Raina et al. (2009) found Vibrio and Shewanella species to be able to degrade the sulfur compounds, e.g. DMSP, DMS and acrylic acid, associated with coral reef tissue and in the surrounding water, suggesting a role for these genera in the biogeochemical cycling of sulfur [31].

Expected was the finding of Desulfovibrio in the SRB culture (Figure 3). During the last two decades, an increasing number of novel sulfate-reducing bacteria have been isolated from a wide variety of environments, where strains of the genus Desulfovibrio are commonly found $[32,33]$. In this study, we detected Desulfovibrio species in the water column at 40 to $400 \mathrm{~m}$ depth, between the oxic and strictly anaerobic zones. Hastings and Emerson (1988) reported sulfate reduction in the presence of oxygen in and above the chemocline of the Cariaco basin and recent reports, using molecular techniques, showed sulfate reducing $\delta$-proteobacteria cells were mainly associated with the oxic-anoxic interface zone and in the water column up to the aerobic zone $(30 \mathrm{~m})$ $[1,5,9]$. The Desulfovibrio phylotypes detected in this study were most similar to the uncultivated environmental clones of sulfate-reducing $\delta$-proteobacteria and those mainly from tropical marine environments (Table 2).

Other bacteria identified among our cultures were Enterobacter, Shewanella, Fusobacterium, Mariniliabilia and Spirochaeta (Table 2 and Figure 3). Spirochaeta genus was report in sediments from Guaymas Basin [34]. Enterobacter sp., Fusobacterium perfoetens and Spirochaeta $\mathrm{sp}$. are active in marine biocorrosion, formation of biofilms on carbon steel surfaces, and corrosion of oil field pipelines [35-37]. Our study showed four bands that were most similar to an uncultured bacterium clone related to Fusobacterium that had been isolated from coral reef samples [15]. Shewanella sp. has been associated with Vibrio sp., in the corrosion of carbon steel in saline media. These facultatively anaerobic bacteria can consume residual oxygen and thereby provide ecological niches for growth of SRB. Depending on environmental conditions, Shewanella sp. can produce hydrogen sulfate from elemental sulfur, reduce ferric iron and use cathodic hydrogen, competing with SRB for $\mathrm{H}_{2}$ as an energy source [38].

The genus Marinilabilia was created to include the marine, facultative anaerobic Cytophaga species, Cytophaga salmonicolor and Cytophaga agarovorans [39]. Taxonomic investigations have shown an overlap between the genera Cytophaga and Flavobacterium and these groups were then called the Cytophaga-Flavobacterium complex. Molecular investigations revealed an unexpected relationship between the Cytophaga-Flavobacterium group and the genus Bacteroides (CFB group) $[39,40]$. The CFB group had previously been reported to occur throughout the entire water column in the Cariaco Basin $[1,9]$, in sediments from Guaymas Basin [34] and in anoxic cultures of rice paddy soil [41]. Our study showed that Marinilabilia salmonicolor, Marinifilum fragile, and an uncultured Bacteroidetes marine species of the CFB group were present, along with SRB, near the redox interface.

The lactate-sulfate media can enrich for SRB using lactate as an electron donor for the reduction of sulfate. However, other anaerobic or facultative microbes not reducing sulfate may also be found. Here we analyzed enrichments which showed the presence of a black FeS 


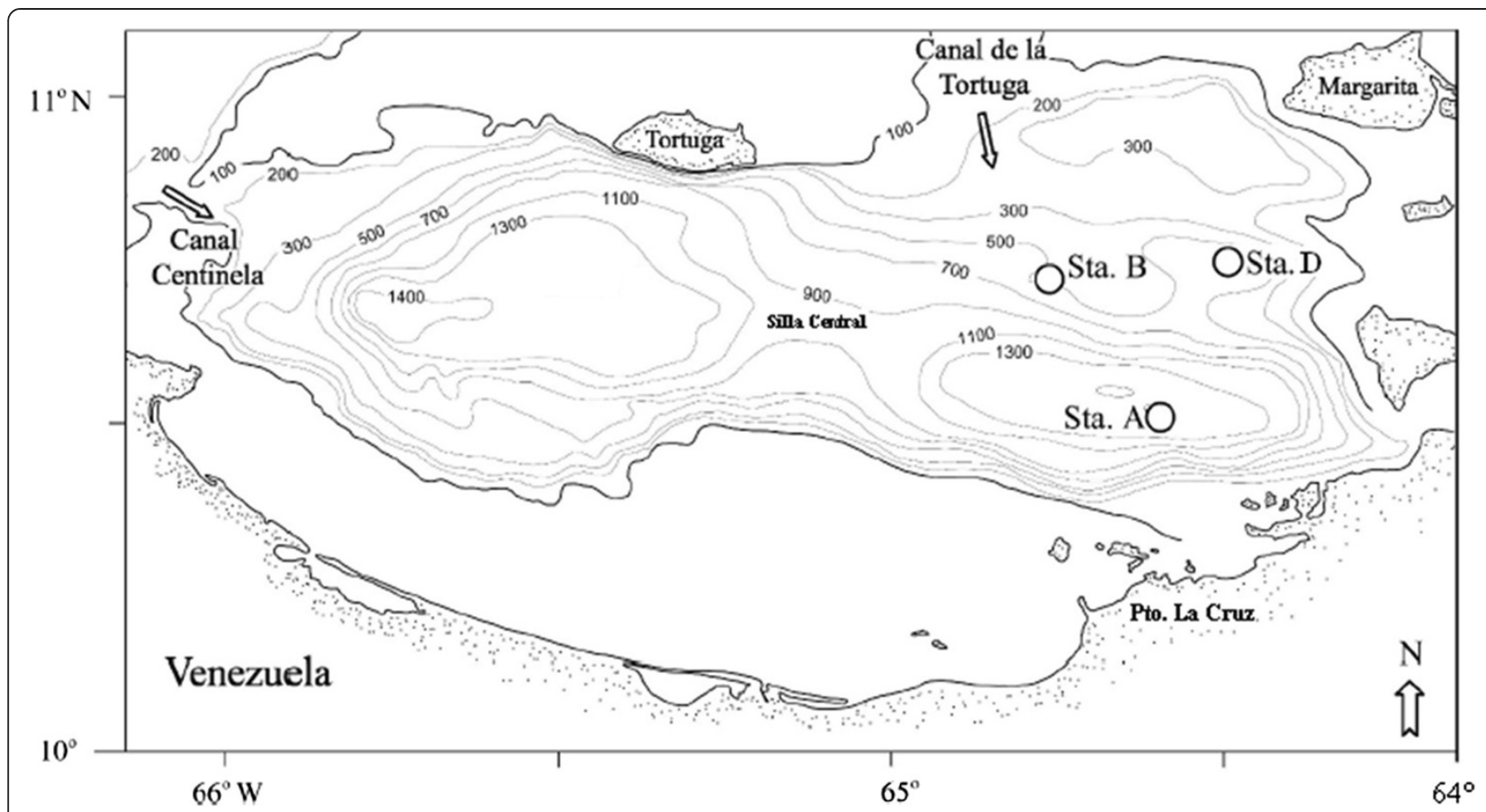

Figure 4 Cariaco basin map. Stations (Sta.) indicated by circles. Isobaths are in meters. Arrows indicate pathways of water intrusion from the Caribbean Sea. Sta. A: Station of oriental depression ( $\left.10^{\circ} 30^{\prime} \mathrm{N}, 64^{\circ} 40^{\prime} \mathrm{O}\right)$; Sta. B: Station $700 \mathrm{~m}$ deep (10 $\left.40^{\prime} \mathrm{N}, 64^{\circ} 45^{\prime} \mathrm{O}\right)$; Sta. D: Station between the Araya and Cubagua sills $\left(10^{\circ} 43^{\prime} \mathrm{N}, 64^{\circ} 32^{\prime} \mathrm{O}\right)$. This figure is adapted from Lin et al. (2008).

precipitate, indicating that some sulfate reduction must have occurred and found by DGGE other bacterial groups like ganma proteobacteria and CFB on those enrichments associated with Desulfovibrio species, showing the lack of specificity of lactate-sulfate media for SRB enrichment.

\section{Conclusions}

Many studies have been conducted to identify the microorganisms present in the stratified environment of the Cariaco Basin and how they influence geochemical processes $[1,3,5]$. The high levels of sulfide present in the basin have been attributed to biological sulfate reduction [6]. However, very few studies have included enrichment for bacteria associated with sulfur cycling in this particular environment. In our studies, we showed an association of SRB-like Desulfovibrio with Vibrio species and other genera that have a previously defined relevant role in sulfur transformation and coupling of carbon and sulfur cycles in an environment where there are variable redox conditions and oxygen availability. This study provides new information about microbial species that were culturable under these conditions at several locations in the Cariaco Basin.

\section{Methods}

Sampling site and physico-chemical measurements The Cariaco Basin is currently the focus of the CARIACO time series, a cooperative United States-Venezuelan research project (http://www.imars.usf.edu/CAR/), and is located on the Venezuelan continental shelf (Figure 4). The basin is isolated from the rest of the Caribbean Sea by a $150 \mathrm{~m}$ deep sill connecting Isla Margarita to Cabo Codera on the Venezuelan mainland $[11,42]$.

Five hundred milliliters of seawater were collected at different depths (40-230, 260-300, and 325-640 $\mathrm{m}$ for oxic, interfase and anoxic water column zones) on May 25-27, 2005, and May 19-20, 2006 (CAR-112 and 122, respectively), at three locations (Figure 4), including the CARIACO time-series station (station A: $10^{\circ} 30^{\prime} \mathrm{N} 64^{\circ}$ $40^{\prime} \mathrm{W}$ ), a station southeast of La Tortuga Channel in water

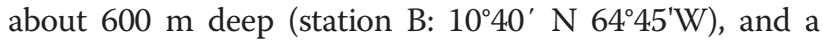
station between the Cubagua and Araya sills (station D: $\left.10^{\circ} 43^{\prime} \mathrm{N} 64^{\circ} 32^{\prime} \mathrm{W}\right)$.

Water column sampling was conducted aboard the R/ $\mathrm{V}$ Hermano Gines, operated by Estación de Investigaciones Marinas (EDIMAR), Fundación la Salle de Ciencias Naturales, Margarita Island, Venezuela and samples were collected with a SeaBird rosette, accommodating 12 TFE-lined, 8-L Niskin bottles. Profiles of temperature, salinity, and $\mathrm{O}_{2}$ were obtained with a Seabird conductivity-temperature-depth (CTD) system with attached SBE 43 oxygen probe. The Niskin bottles were slightly pressurized with $\mathrm{N}_{2}$ during sampling to minimize contact with $\mathrm{O}_{2}$. Based on redox conditions and oxygen content for the sampling cruises, oxic layer was considered between $(\sim 0-240 \mathrm{~m})$; redox transition 
interface $(\sim 245-320 \mathrm{~m})$; and anoxic layer $(\sim 325$ to $900 \mathrm{~m})$

\section{Culture conditions}

Cultivation of SRB in sealed serum bottles containing filter sterilized seawater amended with three different culture media: Twin Pack (Twin) medium (per liter of distilled water: $\mathrm{K}_{2} \mathrm{HPO}_{4}, 2.00 \mathrm{~g}$; $\mathrm{MgSO}_{4} \cdot 7 \mathrm{H}_{2} \mathrm{O}, 0.10 \mathrm{~g}$; $\mathrm{CaCl}_{2} \cdot 2 \mathrm{H}_{2} \mathrm{O}, 0.10 \mathrm{~g}$; ammonium sulphate, $0.10 \mathrm{~g}$; $\mathrm{FeCl}_{3}, 0.02 \mathrm{~g}$; sodium thiosulfate, $10.0 \mathrm{~g} ; \mathrm{pH}$ adjusted at $7,8 \pm 0,2)$ supplemented with $0.2 \%$ lactate; Triple Pack (TP) medium (HIMEDIA, India) supplemented with $0.2 \%$ lactate as a carbon source and a solution of ferrous ammonium sulfate $(0.0392 \mathrm{mg} / \mathrm{L})$ and sodium ascorbate $(0.01 \mathrm{mg} / \mathrm{L})$ as reducing agent; and Modified American Petroleum Institute (API) medium (HIMEDIA, India), supplemented with ascorbic acid $(0.1 \mathrm{~g} / \mathrm{L})$ as a reducing agent [43] and using $0.5 \%$ acetate as a carbon source. Each culture medium was inoculated with $10 \mathrm{~mL}$ of 20 water samples (6 samples for 2005 ; 14 samples for 2006) by duplicate and incubated at room temperature for 30 days under a gas mixture consisting of $20 \% \mathrm{CO}_{2}: 80 \%$ $\mathrm{N}_{2} .120$ cultures were performed in total.

\section{DNA extraction and PCR}

DNA was extracted from the Twin, TP, and API cultures using the Microbial DNA Isolation kit (Mo Bio Laboratories, CA, USA), according to manufacturer's recommendation. Bacterial DNA was amplified using a primer with GC clamp (341F-GC: 5'-CGC CCG CCG CGC GCG GCG GGC GGG GCG GGG GCA CGG GGG GCC TAC GGG AGG CAG CAG-3') and 907R (5'-CCG TCA ATT CGT TTG AGT TT-3') [16,44]. The reaction mixture contained $3 \mu \mathrm{L}$ of DNA (approximately 50-100 ng) and $0.5 \mu \mathrm{M}$ of each primer, $35 \mu \mathrm{L}$ of GoTaq Green Master Mix reactions (Promega, Madison, WI, USA) and water added to a final volume of $70 \mu \mathrm{L}$. PCR amplification was performed in a thermal cycler (PxE Thermal Cycler, Thermo Hybaid, IL, USA), as follows: $95^{\circ} \mathrm{C}$ for 5 min; 20 cycles at $94^{\circ} \mathrm{C}$ for $30 \mathrm{~s} ; 65^{\circ} \mathrm{C}$ for $1 \mathrm{~min} ; 72^{\circ} \mathrm{C}$ for $3 \mathrm{~min} ; 15$ cycles at $94^{\circ} \mathrm{C}$ for $30 \mathrm{~s} ; 55^{\circ} \mathrm{C}$ for $1 \mathrm{~min} ; 72^{\circ} \mathrm{C}$ for $3 \mathrm{~min}$; and $72^{\circ} \mathrm{C}$ for $7 \mathrm{~min}$. The negative PCR control had no template in the reaction. The positive control for PCR was prepared by adding $1 \mu \mathrm{L}$ of Alcaligenes faecalis DNA (100 ng). The PCR products were visualized by running the reaction mixture in a TBE agarose gel (1.0\%), staining with ethidium bromide $(0.2 \mu \mathrm{g} / \mathrm{ml})$, and observing under UV light.

\section{Denaturing gradient gel electrophoresis (DGGE)}

DGGE analysis of the bacterial amplicons $(70 \mu \mathrm{L}$ - entire volume of a PCR reaction) was performed in $6 \%$ polyacrylamide (37.5: 1 acrylamide/bis-acrylamide) gels containing a
0-100\% urea plus formamide gradient (100\% denaturing solution containing $7 \mathrm{M}$ urea and $40 \%$ (v/v) formamide).

Electrophoresis was performed in $0.5 \mathrm{X}$ TAE (TRIS acetate $20 \mathrm{mM}$ [pH 7.41], sodium acetate $10 \mathrm{mM}$, and sodium EDTA $0.5 \mathrm{mM}$ ) at 60 volts and $60^{\circ} \mathrm{C}$ for $14 \mathrm{~h}$ using a DGGE 1001-110 System (C.B.S. Scientific Company, Inc). Gels were stained with ethidium bromide $(0.2 \mu \mathrm{g} / \mathrm{mL})$ for $20 \mathrm{~min}$ and visualized using a FOTO/ Analyst Investigator/FX Systems (Fotodyne Incorporated, Hartland, WI, USA) [12].

\section{S RNA gene sequence analysis}

Separated DNA fragments were excised from the DGGE gels, placed in a freezer at $-80^{\circ} \mathrm{C}$ for $2 \mathrm{~h}$, and blended in Mini-Beadbeater 8 (BioCold Scientific, Fenton, MO, USA), for $3 \mathrm{~min}$ with $0.2 \mathrm{~g}$ sterile zirconia/silica beads (BioSpec Products, Bartlesville, OK) in $500 \mu \mathrm{L}$ sterile HPLC water (Fisher HealthCare). Samples were stored at $4^{\circ} \mathrm{C}$ overnight, after which $3 \mu \mathrm{l}$ aliquots were used as template for PCR amplification of 16S RNA gene, employing primers $341 \mathrm{~F}$ (same as $341 \mathrm{~F}-\mathrm{GC}$ but without GC clamp) and 907R and the same PCR conditions as described above, with a final PCR volume of $50 \mu \mathrm{L}$.

Re-amplified PCR products were purified using a Wizard SV gel and PCR clean-up system kit (Promega, Madison, WI, USA). Sequencing of one DNA strand was performed using the BigDye ${ }^{\mathrm{TM}}$ Terminator v3.1 sequencing kit, following manufacturer's instructions (Applied Biosystems, Foster City, CA). Sequencing reactions were analyzed in a 3100 ABI DNA sequencer and sequence quality was determined using Chromas Lite software (http://www.technelysium. com.au/chromas_lite.html) [12].

The closest known relatives of the partial 16S RNA gene sequences were identified using BLASTN 2.2.1 (http://www.ncbi.nlm.nih.gov/blast/) [45].

\section{Phylogenetic analysis}

Partial 16S rRNA gene sequences initially were compared with sequences in the GenBank database using BLASTN [45] to determine their approximate phylogenetic affiliation. Environmental sequences, together with closest GenBank matches, were aligned in http:// greengenes.lbl.gov using the NAST Alignment utility [46]. Sequences obtained from 23 DGGE bands were aligned using NAST Alignment [46], and a phylogenetic tree was constructed using 200 bp long aligned sequences and the neighbor-joining algorithm (JukesCantor Model) in Molecular Evolutionary Genetics Analysis 2.1 software (MEGA, version 4) [47]. Bootstrapping was used to estimate reliability of the phylogenetic reconstructions (1000 replicates). Representative sequences were submitted to GenBank database and are designated by accession numbers HM466893-HM466915. 


\section{Competing interests}

The authors declare that they have no competing interests.

\section{Authors' contributions}

$\mathrm{LBH}$ participated in the design of the study, carried out the sampling collection and molecular genetic studies, participated in the phylogenetic analyses and the sequence alignment, and co-wrote the manuscript. MAG participated in the phylogenetic analyses of the samples and the sequence alignment, and co-wrote the manuscript. AC participated in the design of the study and coordination of the molecular genetic studies. RV and JJN compiled the physic-chemical data related to the Cariaco Basin and B/O Hermano Gines logistic and sampling collection. RC drafts the manuscript and improves the discussion of the results. PS participated in the design of the study, carried out the sampling collection and the phylogenetic analyses, and co-wrote the manuscript. All authors read and approved the final manuscript.

\section{Acknowledgments}

The authors would like to give special thanks to the Captain and crew of the Hermano Gines, and Yrene Astor and Javier Camparo at the Fundación La Salle in Isla Margarita for their help and logistical support. The authors gratefully acknowledge Maria Jose Rodriguez for her assistance with the DGGE. Special thanks to V. Edgcomb, M. I. Scranton and G. Taylor for assistance in sampling collection. This work was supported by a grant from the National Science Foundation, NSF Grant microbial observatory MCB0348045 to A.C and the Decanato de Investigación y Desarrollo of the Universidad Simón Bolívar to P.S. The hydrographic and other oceanographic observations at the CARIACO Ocean Time Series were supported by NSF Grant OCE-0326268 to Frank Muller-Karger and National Oceanic and Atmospheric Agency (NOAA) Grant No. S0660009 and National Institute of Health Grant No. 2RO1A1039129-11A2-NIH provided support for Rita R. Colwell.

\section{Author details}

${ }^{1}$ Departamento de Biología de Organismos, Universidad Simón Bolívar, Caracas, Venezuela. ${ }^{2}$ Centro de Biofísica y Bioquímica, Instituto Venezolano de Investigaciones Científicas, Caracas, Venezuela. ${ }^{3}$ Department of Biology, University of Louisiana at Lafayette, Lafayette, Louisiana, USA. ${ }^{4}$ EDIMAR, Fundación La Salle, Margarita, Venezuela. ${ }^{5}$ University of Maryland, College Park, Maryland, USA.

Received: 30 May 2012 Accepted: 24 August 2013

Published: 28 August 2013

\section{References}

1. Madrid VM, Taylor GT, Scranton MI, Chistoserdov AY: Phylogenetic diversity of bacterial and archaeal communities in the anoxic zone of the Cariaco Basin. Appl Environ Microbiol 2001, 67:1663-1674.

2. Astor YM, Müller-Karger F, Scranton MI: Seasonal and interannual variation in the hydrography of the Cariaco Basin: implications for basin ventilation. Cont Shelf Res 2003, 23:125-144.

3. Taylor GT, Hein C, labichella M: Temporal variations in viral distributions in the anoxic Cariaco Basin. Aquatic Microbiol Ecol 2003, 30:103-116.

4. Tedesco T, Thunell R, Astor $Y$, Karger FM: The oxygen isotope composition of planktonic foraminifera from the Cariaco Basin, Venezuela: seasonal and interannual variations. Mar Micropaleontol 2007, 62:180-193.

5. Lin X, Scranton MI, Chistoserdov AY, Varela R, Taylor G: Spatiotemporal dynamics of bacterial populations in the anoxic Cariaco Basin. Limnol Oceanogr 2008, 53:37-51.

6. Hasting D, Emerson S: Sulfate reduction in the presence of low oxygen levels in the water column of the Cariaco Trench. Limnol Oceanogr 1988 33:391-396.

7. Tuttle JH, Jannasch HW: Sulfide and thiosulfate-oxidizing bacteria in anoxic marine basins. Mar Biol 1973, 20:64-70.

8. Morris I, Glover HE, Kaplan WA, Kelly DP, Weightman AL: Microbial activity in the Cariaco Trench. Microbios 1985, 42:133-144.

9. Lin X, Wakeham SG, Putman IF, Astor YM, Scranton MI, Chistoserdov AY, Taylor GT: Comparison of vertical distributions of prokaryotic assemblages in the anoxic Cariaco Basin and Black Sea by use of fluorescence in situ hybridization. Appl Environ Microbiol 2006, 72:2679-2690.
10. Lin X, Scranton MI, Varela R, Chistoserdov AY, Taylor GT: Compositional responses of bacterial communities to redox gradients and grazing in the anoxic Cariaco Basin. Aquat Microb Ecol 2007, 47:57-72.

11. Müller-Karger F, Varela R, Thunell R, Scranton MI, Bohrer R, Taylor G, Capelo J, Astor Y, Tappa E, Ho T-Y, Walsh JJ: Annual cycle of primary production in the Cariaco Basin: response to upwelling and implications for vertical export. J Geophys Res 2001, 106:4527-4542.

12. Garcia-Amado MA, Bozo-Hurtado L, Astor Y, Suarez P, Chistoserdov A: Denaturing gradient gel electrophoresis analyses of the vertical distribution and diversity of Vibrio spp. populations in the Cariaco Basin. FEMS Microbiol Ecol 2011, 77:347-356.

13. Hirayama H, Sunamura M, Takai K, Nunoura T, Noguchi T, Oida H, Furushima Y, Yamamoto H, Oomori T, Horikoshi K: Culture-dependent and independent characterization of microbial communities associated with a shallow submarine hydrothermal system occurring within a coral reef off Taketomi Island, Japan. Appl Environ Microbiol 2007, 73:7642-7656.

14. Koizumi Y, Kojima H, Fukui M: Potential sulfur metabolisms and associated bacteria within anoxic surface sediment from saline meromictic Lake Kaiike (Japan). FEMS Microbiol Ecol 2005, 52:297-305.

15. Garren M, Raymundo L, Guest J, Harvell CD, Azam F: Resilience of coralassociated bacterial communities exposed to fish farm effluent. PLOS ONE 2009, 4:1-9.

16. Schäfer H, Muyzer G: Denaturing gradient gel electrophoresis in marine microbial ecology. In Marine Microbiology, Methods in Microbiology, Volume 30. Edited by Paul JH. London: Academic Press; 2001:425-468.

17. Teske A, Sigalevich P, Cohen Y, Muyzer G: Molecular identification of bacteria from a coculture by denaturing gradient gel electrophoresis of $16 \mathrm{~S}$ ribosomal DNA fragments as a tool for isolation in pure cultures. Appl Environ Microbiol 1996, 62:4210-4215.

18. Thompson FL, lida T, Swings J: Biodiversity of vibrios. Microbiol Mol Biol Rev 2004, 68:403-431.

19. Gomez-Gil B, Thompson FL, Thompson CC, Swings J: Vibrio rotiferianus sp. nov., isolated from cultures of the rotifer Brachionus plicatilis. Int J Syst Evol Microbiol 2003, 53:239-243.

20. Sawabe T, Kita-Tsukamoto K, Thompson FL: Inferring the evolutionary history of vibrios by means of multilocus sequence analysis. J Bacteriol 2007, 189:7932-7936.

21. Alvarez JD, Austin B, Alvarez AM, Reyes H: Vibrio harveyi: a pathogen of penaeid shrimps and fish in Venezuela. J Fish Dis 1998, 21:313-316.

22. Pujalte MJ, Sitja-Bobadilla A, Maclan MC, Belloch C, Alvarez-Pellitero P, PerezSanchez J, Uruburu F, Garay E: Virulence and molecular typing of Vibrio harveyi strains isolated from cultured dentex, gilthead sea bream and European sea bass. Syst Appl Microbiol 2003, 26:284-292.

23. Lavilla-Pitogo CR, Leaño EM, Paner MG: Mortalities of pond-cultured juvenile shrimp, Penaeus monodon, associated with dominance of luminescent vibrios in the rearing environment. Aquaculture 1998, 164:337-349.

24. Bourne DG, Høj L, Webster NS, Swan J, Hall MR: Biofilm development within a larval rearing tank of the tropical rock lobster, Panulirus ornatus. Aquaculture 2006, 260:27-38.

25. Sutherland KP, Porter JW, Torres C: Disease and immunity in Caribbean and Indo-Pacific zooxanthellate corals. Mar Ecol Prog Ser 2004, 266:273-302.

26. Banin E, Israely T, Kushmaro A, Loya Y, Orr E, Rosenberg E: Penetration of the coral-bleaching bacterium Vibrio shiloi into Oculina patagonica. Appl Environ Microbiol 2000, 66:3031-3036.

27. Kushmaro A, Banin E, Loya Y, Stackebrandt E, Rosenberg E: Vibrio shiloi sp. nov., the causative agent of bleaching of the coral Oculina patagonica. Int J Syst Evol Microbiol 2001, 51:1383-1388.

28. Thompson FL, Hoste B, Thompson CC, Huys G, Swings J: The coral bleaching vibrio shiloi kushmaro et al. 2001 Is a later synonym of vibrio mediterranei pujalte and garay 1986. Syst Appl Microbiol 2001 24:516-519.

29. Chimetto LA, Brocchi M, Gondo M, Thompson CC, Gomez-Gil B, Thompson FL: Genomic diversity of vibrios associated with the Brazilian coral Mussismilia hispida and its sympatric zoanthids (Palythoa caribaeorum, Palythoa variabilis and Zoanthus solanderi). J Appl Microbiol 2009, 106:1818-1826.

30. Teplitski M, Ritchie K: How feasible is the biological control of coral diseases? Trends Ecol Evol 2009, 24:378-385.

31. Raina JB, Tapiolas D, Willis BL, Bourne DG: Coral-associated bacteria and their role in the biogeochemical cycling of sulfur. Appl Environ Microbiol 2009, 75:3492-3501. 
32. Teske A, Wawer C, Muyzer G, Ramsing NB: Distribution of sulfate-reducing bacteria in a stratified fjord (Mariager Fjord, Denmark) as evaluated by most-probable-number counts and denaturing gradient gel electrophoresis of PCR-amplified ribosomal DNA fragments. Appl Environ Microbiol 1996, 62:1405-1415.

33. Basso O, Caumette P, Magot M: Desulfovibrio putealis sp. nov., a novel sulfate-reducing bacterium isolated from a deep subsurface aquifer. Int J Syst Evol Microbiol 2005, 55:101-104.

34. Dhillon A, Teske A, Dillon J, Stahl DA, Sogin ML: Molecular characterization of sulfate-reducing bacteria in the Guaymas Basin. Appl Environ Microbiol 2003, 69:2765-2772

35. Neria-González I, Wang ET, Ramírez F, Romero JM, Hernández-Rodríguez C: Characterization of bacterial community associated to biofilms of corroded oil pipelines from the southeast of Mexico. Anaerobe 2006, 12:122-133.

36. Bermont-Bouis D, Janvier M, Grimont PA, Dupont I, Vallaeys T: Both sulfatereducing bacteria and Enterobacteriaceae take part in marine biocorrosion of carbon steel. J Appl Microbiol 2007, 102:161-168.

37. Agrawal A, Vanbroekhoven K, Lal B: Diversity of culturable sulfidogenic bacteria in two oil-water separation tanks in the north-eastern oil fields of India. Anaerobe 2010, 16:12-18.

38. Herrera LK, Videla HA: Role of iron-reducing bacteria in corrosion and protection of carbon steel. Int Biodeterioration \& Biodegradation 2009, 63:891-895.

39. Nakagawa Y, Yamasato K: Emendation of the genus Cytophaga and transfer of Cytophaga agarovorans and Cytophaga salmonicolor to Marinilabilia gen. nov.: phylogenetic analysis of the FlavobacteriumCytophaga complex. Int J Syst Bacteriol 1996, 46:599-603.

40. Suzuki M, Nakagawa Y, Harayama S, Yamamoto S: Phylogenetic analysis of genus Marinilabilia and related bacteria based on the amino acid sequences of GyrB and emended description of Marinilabilia salmonicolor with Marinilabilia agarovorans as its subjective synonym. Int J Syst Bacteriol 1999, 49:1551-1557.

41. Hengstmann U, Chin K-J, Janssen PH, Liesack W: Comparative phylogenetic assignment of environmental sequences of genes encoding 16S rRNA and numerically abundant culturable bacteria from an anoxic rice paddy soil. Appl Environ Microbiol 1999, 65:5050-5058.

42. Müller-Karger F, Varela R, Thunell R, Scranton MI, Bohrer R, Taylor G, Capelo J, Astor Y, Tappa E, Ho T-Y, labichella M, Walsh JJ, Diaz JR: Sediment record linked to surface processes in the Cariaco Basin. EOS. AGU Transactions American Geophysical Union 2000, 81:529-535.

43. HiMedia Laboratories: The HiMedia Manual for Microbiology Laboratory Practice. India; 1998.

44. Muyzer $G$, De Waal E, Uitterlinden A: Profiling of complex microbial populations by denaturing gradient gel electrophoresis analysis of polymerase chain reaction-amplified genes coding for 16S rRNA. Appl Environ Microbiol 1993, 59:695-700.

45. Altschul SF, Madden TL, Schäffer AA, Zhang J, Zhang Z, Miller W, Lipman DJ: Gapped BLAST and PSI-BLAST: a new generation of protein database search programs. Nucleic Acids Res 1997, 25:3389-3402.

46. DeSantis TZ, Hugenholtz P, Keller K, Brodie EL, Larsen N, Piceno YM, Phan $R$, Andersen GL: NAST: a multiple sequence alignment server for comparative analysis of 16S rRNA genes. Nucleic Acids Res 2006 34:W394-W399.

47. Tamura K, Dudley J, Nei M, Kumar S: MEGA4: molecular evolutionary genetics analysis (MEGA) software version 4.0. Mol Biol Evol 2007, 24:1596-1599.

doi:10.1186/2046-9063-9-17

Cite this article as: Bozo-Hurtado et al.: Identification of bacteria in enrichment cultures of sulfate reducers in the Cariaco Basin water column employing Denaturing Gradient Gel Electrophoresis of $16 \mathrm{~S}$ ribosomal RNA gene fragments. Aquatic Biosystems 2013 9:17.

\section{Submit your next manuscript to BioMed Central and take full advantage of:}

- Convenient online submission

- Thorough peer review

- No space constraints or color figure charges

- Immediate publication on acceptance

- Inclusion in PubMed, CAS, Scopus and Google Scholar

- Research which is freely available for redistribution

Submit your manuscript at www.biomedcentral.com/submit 